\title{
Induction of HL-60 Differentiation By Starvation for a Single Essential Amino Acid but Not By Protein Synthesis Inhibitors
}

\author{
Renate B. Pilz, Georges Van den Berghe,* and Gerry R. Boss \\ Department of Medicine, University of California at San Diego, San Diego, California 92103; \\ and *International Institute of Cellular and Molecular Pathology, Brussels, Belgium
}

\begin{abstract}
Starvation for a single essential amino acid induced differentiation of the human promyelocytic leukemia line HL-60 into morphologically and functionally mature granulocytes. Differentiation occurred when protein synthesis was inhibited up to $90 \%$ but was not simply secondary to growth arrest or protein synthesis inhibition, because neither glucose starvation nor treatment with protein synthesis inhibitors induced differentiation. Induction of differentiation by an aminoacyl tRNA synthetase inhibitor and the effect of cycloheximide and puromycin on amino acid-starved cells suggested an important regulatory role of tRNA molecules during differentiation.
\end{abstract}

\section{Introduction}

During cellular differentiation, quantitative and qualitative changes in gene expression occur. The underlying regulatory mechanisms are poorly understood but operate at the transcriptional, translational and posttranslational levels $(1,2)$. A better understanding of these regulatory mechanisms could lead to new forms of therapy of acute human leukemias where the cells are arrested at different stages of maturation (3). The human promyelocytic leukemic cell line HL-60 is an established model for studying hematopoietic cell differentiation in vitro $(4,5)$. These immature cells can be induced by various compounds to differentiate along either the granulocytic or monocytic lineage into functionally and morphologically mature nonproliferating cells $(4,5)$.

We found that starvation for a single essential amino acid induced granulocytic differentiation of HL-60 cells. Changes in tRNA molecules appeared to play an important regulatory role in the differentiation process because $(a)$ the degree of differentiation correlated with the degree of amino acid starvation (tRNA aminoacylation varies with amino acid availability), (b) histidinol, an aminoacyl tRNA synthetase inhibitor, induced differentiation, and $(c)$ cycloheximide prevented differentiation in amino acid-starved cells whereas puromycin had a much weaker effect.

Address reprint requests to Gerry R. Boss, M.D., Department of Medicine, H-811H, UCSD Medical Center, 225 Dickinson Street, San Diego, CA 92103.

Received for publication 3 October 1986.

J. Clin. Invest.

(C) The American Society for Clinical Investigation, Inc.

0021-9738/87/03/1006/04 \$1.00

Volume 79, March 1987, 1006-1009

\section{Methods}

Origin of cell line and culture conditions. The human promyelocytic cell line HL-60 was obtained from Dr. Karen Willard-Gallo of the International Institute of Cellular and Molecular Pathology, Brussels, Belgium; she had previously obtained it from the American Type Culture Collection, Rockville, MD. The cells were routinely grown in RPMI-1640 medium (Irvine Scientific Co., Irvine, CA) supplemented with $2 \mathrm{mM}$ glutamine and 10\% fetal bovine serum (FBS) (Irvine Scientific Co.); they were diluted biweekly to a density of $0.15 \times 10^{6}$ cells $/ \mathrm{ml}$.

Cells were recovered by centrifugation from the growth medium and resuspended at a density of $0.15 \times 10^{6}$ cells $/ \mathrm{ml}$ in experimental medium consisting of RPMI-1640 medium lacking one amino acid or glucose that was supplemented with $2 \mathrm{mM}$ glutamine, $5 \mathrm{ng} / \mathrm{ml}$ sodium selenate and $10 \%$ horse serum (Irvine Scientific Co.) that had been heat-inactivated at $56^{\circ} \mathrm{C}$ for $30 \mathrm{~min}$ and extensively dialyzed against $0.9 \% \mathrm{NaCl}$. The amino acid or glucose was added to the desired concentration. When this concentration was the same as in the formulation for RPMI-1640 medium, the medium was referred to as complete experimental medium. The cells were cultured in 6 -well cluster dishes at $37^{\circ} \mathrm{C}$ in a $95 \%$ air $/ 5 \%$ $\mathrm{CO}_{2}$ humidified atmosphere. Cycloheximide, emetine, puromycin, or dimethyl sulfoxide (DMSO) was added to some of the cultures in complete experimental medium at time zero.

Measurement of $H L-60$ differentiation. Differentiation of HL-60 cells along the myelocytic series requires 4-7 d $(4,5)$. In fully differentiated HL-60 cells, as in normal granulocytes, membrane perturbation (e.g., by phorbol-12-myristate-13-acetate [PMA] ${ }^{1}$ ) stimulates a number of biochemical reactions collectively referred to as the phagocytic "respiratory burst" (6). These reactions include superoxide anion production and increased glucose oxidation via the pentose phosphate pathway; they can be assessed by counting the number of nitroblue tetrazolium (NBT) reducing cells or by measuring ${ }^{14} \mathrm{CO}_{2}$ release from $\left[1-{ }^{14} \mathrm{C}\right]$ glucose, respectively (6). Unless otherwise noted, measurements of HL-60 differentiation were performed on day 6 of culture.

For the studies with NBT, which assesses functional maturity on an individual cell basis, $1 \times 10^{6}$ cells were incubated for $30 \mathrm{~min}$ at $37^{\circ} \mathrm{C}$ in $0.5 \mathrm{ml}$ phosphate-buffered saline with $1 \mathrm{mg} / \mathrm{ml} \mathrm{NBT}, 100 \mathrm{ng} / \mathrm{ml} \mathrm{PMA}$, and $20 \%$ dialyzed FBS. At least 200 cells were evaluated per culture and only cells containing at least three blue-black precipitates were counted as positive.

For the measurement of $\left[1-{ }^{14} \mathrm{C}\right]$ glucose oxidation, which quantitatively measures functional maturation of the cell population, $5 \times 10^{6}$ cells were recovered by centrifugation from each of the duplicate cultures. They were resuspended at a density of $1.5 \times 10^{6} \mathrm{cells} / \mathrm{ml}$ in glucose-free, Hepes-buffered RPMI-1640 medium supplemented with $2 \mathrm{mM}$ glutamine and $2 \mathrm{mg} / \mathrm{ml}$ dialyzed bovine serum albumin. Two $1-\mathrm{ml}$ aliquots of this cell suspension were transferred to $16 \times 100-\mathrm{mm}$ glass tubes, and PMA was added to one aliquot at a final concentration of $50 \mathrm{ng} / \mathrm{ml}$. After 5 min at $37^{\circ} \mathrm{C}$ in a shaking water bath, $0.4 \mu \mathrm{Ci}$ of $\left[1-{ }^{14} \mathrm{C}\right]$ glucose (final

1. Abbreviations used in this paper: NBT, nitroblue tetrazolium; PMA, phorbol-12-myristate-13-acetate. 
concentration $1 \mathrm{mM}$; Amersham Corp., Arlington Heights, IL) was added, and the reaction was terminated 20 min later by adding perchloric acid. ${ }^{14} \mathrm{CO}_{2}$ was collected and counted as previously described (7). The assay was linear to $30 \mathrm{~min}$ and at cell densities between 0.5 to $2.5 \times 10^{6}$ cells/ $\mathrm{ml}$. The data are expressed as nmol of ${ }^{14} \mathrm{CO}_{2}$ released per 30 min per $10^{6}$ cells. PMA-stimulated $\left[1{ }^{14} \mathrm{C}\right]$ glucose oxidation was the difference in values between the presence and absence of PMA.

Morphological maturation was determined by Wright's stain; at least 200 cells were counted and slides were reviewed in a blinded fashion by a hematologist. The percent of cells that had differentiated into metamyelocytes and granulocytes correlated approximately with the percent NBT positive cells.

Measurement of cell growth and protein synthesis. Cell increment was calculated from the cell density at day 0 and day 4 measured by Coulter counter (Coulter Electronics, Hialeah, FL); the control cultures grew exponentially during this time. When control cultures were fed on day 3 by a 1:6 dilution with fresh medium, exponential growth continued until day 6; cell viability and the degree of spontaneous differentiation on day 6 were similar in the nonfed and fed control cultures. Cell viability was determined by trypan blue exclusion and exceeded $85 \%$ in all cultures. Protein synthesis was measured after $48 \mathrm{~h}$ of culture by $1 \mathrm{~h}$ of $\left[{ }^{3} \mathrm{H}\right]$ leucine incorporation into acid-precipitable material as described previously (8). Protein synthesis in amino acid-deficient or glucose-deficient cultures decreased until this time, remaining relatively constant thereafter. In preliminary experiments we found no difference in $\left[{ }^{3} \mathrm{H}\right]$ leucine incorporation when control cells were incubated in their original medium or fresh medium, thus indicating little change in the leucine concentration over the first $48 \mathrm{~h}$ of culture.

\section{Results}

HL-60 differentiation during amino acid starvation. When HL60 cells were cultured in experimental medium that contained a growth-limiting concentration, 3-10 $\mu \mathrm{M}$, of an essential amino acid, a large proportion of the cells differentiated into morphologically and functionally mature metamyelocytes and granulocytes after $6 \mathrm{~d}$ (Fig. 1). Similar results were obtained at $3 \mu \mathrm{M}$ of these three amino acids or with $10 \mu \mathrm{M}$ of arginine, isoleucine or lysine. The concentration of these latter three amino acids in complete medium is $1.15 \mathrm{mM}, 380 \mu \mathrm{M}$, and $274 \mu \mathrm{M}$, respectively. Differentiation was not observed when a nonessential amino acid, e.g., proline or serine, was either omitted from the medium or present at $10 \mu \mathrm{M}$. When the effect of starvation for different essential amino acids was compared, there was a noticeable correlation between the degree of growth and protein synthesis inhibition and the degree of differentiation (Fig. 1). The degree of differentiation during valine starvation was similar to that obtained with $1 \%$ DMSO, an established and very effective inducer of HL-60 differentiation (5). Cycloheximide, puromycin, or emetine, at concentrations that inhibited growth and protein synthesis to similar degrees as did amino acid starvation, did not induce differentiation (Fig. 1). Moreover, when cells were incubated in growth-limiting glucose concentrations, $10-500$ $\mu \mathrm{M}$, growth and protein synthesis were inhibited similarly as for cells in amino acid-deficient medium, but differentiation was not observed (results with $100 \mu \mathrm{M}$ glucose are shown in Fig. 1). Thus, differentiation during amino acid starvation was not simply secondary to growth or protein synthesis inhibition but appeared related to some factor unique to amino acid starvation that correlated with the degree of starvation.

Time course of HL-60 differentiation during amino acid starvation. A significant increase in PMA-stimulated [1${ }^{14} \mathrm{C}$ ]glucose oxidation was detected as early as $48 \mathrm{~h}$ after initiation of cultures in either tyrosine-free medium or in medium containing $3 \mu \mathrm{M}$ tyrosine (Fig. 2, open squares and circles, solid lines). At this time, tyrosine had to be added to the tyrosine-free cultures to prevent cell death; $\sim 50-60 \%$ of cells in these tyrosine-added cultures were NBT reducing at days 5-6 when PMA-stimulated $\left[1-{ }^{14} \mathrm{C}\right]$ glucose oxidation was maximal (Fig. 2, closed squares, dotted lines). In cells cultured in medium containing $10 \mu \mathrm{M}$ tyrosine (open triangles, solid lines), maturation lagged $\sim 1 \mathrm{~d}$ behind that of cultures in $3 \mu \mathrm{M}$ tyrosine (open circles, solid lines), but by day 7 both were as morphologically and functionally mature as cells cultured in 1-1.2\% DMSO.

Commitment to terminal differentiation occurred during amino acid starvation with the time to commitment dependent on the initial amino acid concentration. In cells cultured in 3 $\mu \mathrm{M}$ tyrosine, commitment occurred between 48 and $72 \mathrm{~h}$. Thus, when $50 \mu \mathrm{M}$ tyrosine was added at $48 \mathrm{~h}$, PMA-stimulated [1${ }^{14} \mathrm{C}$ ]glucose oxidation was maximal on day 5 (Fig. 2, solid circles,
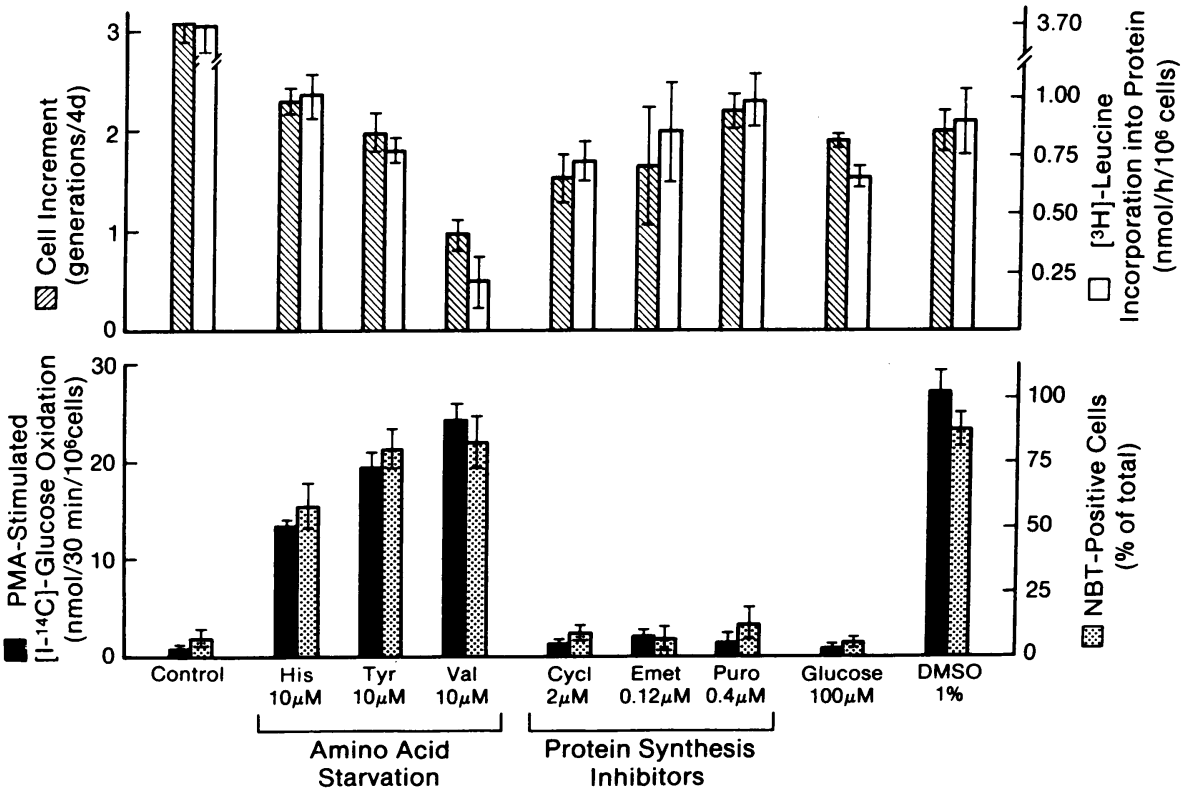

Figure 1. Effect of amino acid starvation, protein synthesis inhibitors, glucose starvation, and DMSO on HL-60 cells. Top, growth and protein synthesis; bottom, differentiation. Cultures were initiated at a density of $0.15 \times 10^{6}$ cells $/ \mathrm{ml}$ in either complete experimental medium containing $72 \mu \mathrm{M}$ histidine, $110 \mu \mathrm{M}$ tyrosine, $400 \mu \mathrm{M}$ valine, and $10 \mathrm{mM}$ glucose, or in otherwise complete medium containing either $10 \mu \mathrm{M}$ histidine, $10 \mu \mathrm{M}$ tyrosine, $10 \mu \mathrm{M}$ valine, or $100 \mu \mathrm{M}$ glucose. Cycloheximide (Cycl), emetine (Emet), puromycin (Puro), or DMSO was added at the indicated concentration at time zero to cultures in complete medium. Cell growth, protein synthesis, and functional maturation, as assessed by PMA-stimulated $\left[1-{ }^{14} \mathrm{C}\right]$ glucose oxidation and NBT reduction, were measured as described fully under Methods. All values are the mean $\pm S D$ of at least three independent experiments performed in duplicate. 


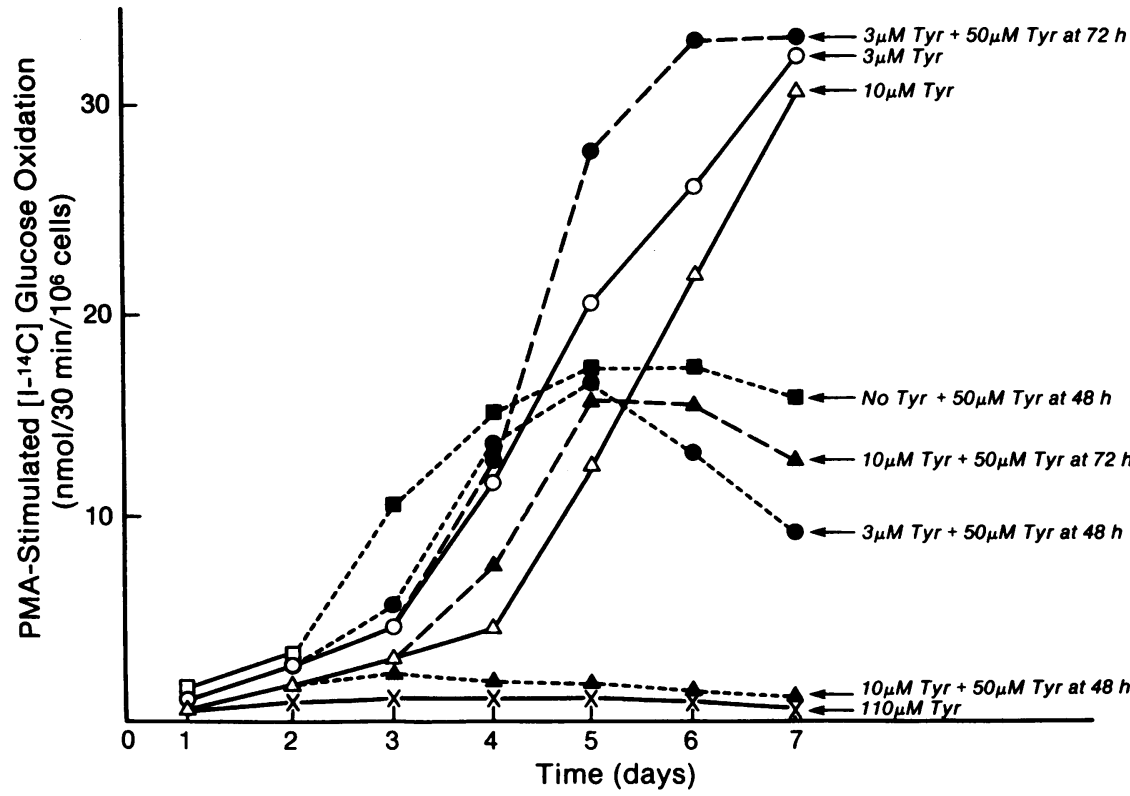

Figure 2. Time course of HL-60 differentiation in tyrosine-deficient medium. Cells were cultured in otherwise complete medium that was lacking tyrosine as described in the legend to Fig. 1. At time zero tyrosine was added to the following concentrations: $110 \mu \mathrm{M}(X) ; 10 \mu \mathrm{M}$ (triangles); $3 \mu \mathrm{M}$ (circles); and no tyrosine added (squares). Some of the cultures received no additional tyrosine (solid lines, open symbols) whereas $50 \mu \mathrm{M}$ tyrosine, which is sufficient to support completely normal growth, was added to others at either $48 \mathrm{~h}$ (dotted lines, closed symbols) or $72 \mathrm{~h}$ (dashed lines, closed symbols). After $48 \mathrm{~h}$, cultures in medium without tyrosine had $25 \%$ trypan blue positive cells; in all other cultures $>85 \%$ of the cells excluded trypan blue. Differentiation was determined by measuring PMA-stimulated ${ }^{14} \mathrm{CO}_{2}$ release from $\left[1-{ }^{14} \mathrm{C}\right]$ glucose as described under Methods. The values are the means of two independent experiments performed in duplicate. dotted lines) with only $\sim 40-50 \%$ of the cells reducing NBT. The decrease in PMA-stimulated $\left[1-{ }^{14} \mathrm{C}\right]$ glucose oxidation after day 5 could be explained by the continued growth of the undifferentiated cells (data not shown). In contrast, addition of 50 $\mu \mathrm{M}$ tyrosine at $72 \mathrm{~h}$ did not inhibit differentiation (Fig. 2, closed circles, dashed lines). In cells cultured in $10 \mu \mathrm{M}$ tyrosine commitment lagged $\sim 1 \mathrm{~d}$ behind that of cells in $3 \mu \mathrm{M}$ tyrosine. Thus, $50 \mu \mathrm{M}$ tyrosine added at $48 \mathrm{~h}$ completely prevented differentiation (Fig. 2, closed triangles, dotted lines), but when added at $72 \mathrm{~h}$ a time course of PMA stimulation (Fig. 2, closed triangles, dashed lines) and NBT reduction was found that was similar to that observed in the $3 \mu \mathrm{M}$ tyrosine cultures that had $50 \mu \mathrm{M}$ tyrosine added at $48 \mathrm{~h}$. These findings are in agreement with previous observations that the portion of cells that become committed to differentiation is dependent on inducer exposure time and concentration (9).

HL-60 differentiation during histidinol treatment. Histidinol is a specific histidine aminoacyl tRNA synthetase inhibitor and consequently causes nonaminoacylated (uncharged) tRNA ${ }^{\text {His }}$ to accumulate $(10,11)$. When $1 \mathrm{mM}$ histidinol was added at day 0 to cells in complete experimental medium, which contains 72 $\mu \mathrm{M}$ histidine, PMA-stimulated $\left[1-{ }^{14} \mathrm{C}\right]$ glucose oxidation was $15.2 \pm 1.9 \mathrm{nmol} / 30 \mathrm{~min} / 10^{6}$ cells on day 6 , and $\sim 71 \pm 11 \%$ of the cells reduced NBT (values are means \pm SD of three independent experiments performed in duplicate). This degree of differentiation was slightly greater than that found when cells were incubated in $10 \mu \mathrm{M}$ histidine (Fig. 1) but approximated that found when cells were incubated in $3 \mu \mathrm{M}$ histidine (data not shown). Induction of differentiation by histidinol was competitive with the medium histidine concentration with a ratio of $\sim$ 12:1 generally yielding maximal differentiation.

Effect of cycloheximide and puromycin on HL-60 differentiation during amino acid starvation. Cycloheximide and puromycin inhibit protein synthesis by different mechanisms. $\mathrm{Cy}$ cloheximide inhibits ribosomal peptidyl synthetase activity whereas puromycin allows peptide bond formation to proceed with release of incomplete peptides (12). In amino acid-starved cells cycloheximide increases the degree of tRNA aminoacylation whereas puromycin does not $(13,14)$. We found that cyclohex- imide added to cultures in medium containing $3 \mu \mathrm{M}$ or $10 \mu \mathrm{M}$ tyrosine completely prevented differentiation without affecting cell growth or viability whereas puromycin only partly prevented differentiation of these starved cells (Table I).

\section{Discussion}

It is remarkable that the numerous morphological and functional changes associated with differentiation can occur during amino acid starvation when protein synthesis is $<10 \%$ of control values (as measured at $48 \mathrm{~h}$ when cultures were initiated in $10 \mu \mathrm{M}$ valine [Fig. 1] or $3 \mu \mathrm{M}$ tyrosine [data not shown]). This suggests efficient regulation of gene expression. Amino acid starvation decreases rRNA and tRNA synthesis with little change initially in mRNA synthesis $(10,14,15)$. In HeLa cells amino acid analogues, which partially mimic the effect of amino acid starvation, initiate a stress response with preferential translation of stressrelated mRNAs and inhibition of translation of nonstress-related

Table I. Effect of Protein Synthesis

Inhibitors on Amino Acid-starved Cells

\begin{tabular}{llc}
\hline Culture condition & $\begin{array}{l}\text { PMA-stimulated } \\
{\left[1^{-14} \text { Clglucose }\right.} \\
\text { oxidation }\end{array}$ & $\begin{array}{l}\text { \% NBT } \\
\text { positive } \\
\text { cells }\end{array}$ \\
\hline & $n m o l / 10^{6}$ cells $/ 30 \mathrm{~min}$ & \% of total \\
Control & $0.44 \pm 0.22$ & $6 \pm 3$ \\
$10 \mu \mathrm{M}$ Tyr & $19.4 \pm 1.95$ & $80 \pm 4$ \\
$10 \mu \mathrm{M}$ Tyr $+1 \mu \mathrm{M}$ cycloheximide & $0.94 \pm 0.25$ & $9 \pm 6$ \\
$10 \mu \mathrm{M}$ Tyr $+0.4 \mu \mathrm{M}$ puromycin & $10.9 \pm 2.2$ & $42 \pm 12$
\end{tabular}

Cultures were initiated in experimental medium containing $110 \mu \mathrm{M}$ tyrosine (control), or $10 \mu \mathrm{M}$ tyrosine in the presence or absence of protein synthesis inhibitors; after $6 \mathrm{~d}$, the degree of differentiation was assessed as described under Methods. Cycloheximide had no additional inhibitory effect on cell growth in tyrosine-deficient media whereas puromycin decreased the final cell count by $\sim 10 \%$. Amount of protein synthesis inhibition was similar with both drugs. 
mRNAs (16). Similar mRNA discrimination may be operative during amino acid starvation of HL-60 cells and this may be one of the mechanisms controlling gene expression during myeloid cell differentiation.

In addition to changes in RNA synthesis, a variety of other metabolic changes occur when mammalian cells are deprived of an essential amino acid. Most of these also occur during protein synthesis inhibitor treatment or glucose starvation $(7,8$, 17). However, decreased aminoacylation of the cognate tRNA with uncharged tRNA accumulation is unique to amino acid starvation $(11,13)$ suggesting that uncharged tRNA molecules were involved in HL-60 differentiation during amino acid starvation. Two other pieces of evidence also suggest that uncharged tRNA molecules were important in the induction of HL-60 differentiation by amino acid starvation: first, the induction of differentiation by histidinol with the inverse correlation between the degree of differentiation and the medium histidine concentration, and second, the differential effect of cycloheximide and puromycin on differentiation during amino acid starvation.

Significant qualitative and quantitative changes in tRNA isospecies occur during differentiation of plant cotyledons, insect larvae, amphibian embryos, and mouse erythroleukemia cells, thus suggesting an important regulatory role of tRNA during cellular differentiation $(18,19)$. Amino acid starvation can cause unequal aminoacylation of the cognate tRNA isospecies (18), and because of tRNA hypomodification can cause changes in both cognate and noncognate tRNA isospecies (20). Changes in the intracellular availability of certain aminoacylated tRNA isospecies can lead to mRNA discrimination $(21,22)$. Amino acid starvation of HL-60 cells may allow further elucidation of the mechanisms involved in the regulation of gene expression during human myeloid differentiation and, in particular, the role of tRNA molecules.

\section{Acknowledgments}

We thank Mrs. Deborah Lundemo for her extremely skillful preparation of the manuscript.

Dr. Pilz was supported by North Atlantic Treaty Organization Scholarship Grant 300/002/501/6 issued by the Deutscher Akademischer Austauschdienst. Dr. Van den Berghe was supported by Fonds National de la Recherche Medicale Grant 3.4563.82 of the Belgian Fonds National de la Recherche Scientifique. Dr. Boss is a Henry J. Kaiser Family Foundation Scholar in General Internal Medicine.

\section{References}

1. Nevins, J. R. 1983. The pathway of eukaryotic mRNA formation. Annu. Rev. Biochem. 52:441-466.

2. Revel, M., and Y. Groner. 1978. Post-transcriptional and translational controls of gene expression in eukaryotes. Annu. Rev. Biochem. 47:1079-1126.

3. Sachs, L. 1978. Control of normal cell differentiation and the phenotypic reversion of malignancy in myeloid leukaemia. Nature (Lond.). 274:535-539.
4. Collins, S. J., R. C. Gallo, and R. E. Gallagher. 1977. Continuous growth and differentiation of human myeloid leukaemic cells in suspension culture. Nature (Lond.). 270:347-349.

5. Collins, S. J., R. W. Ruscetti, R. E. Gallagher, and R. C. Gallo. 1978. Terminal differentiation of human promyelocytic leukemia cells induced by dimethyl sulfoxide and other polar compounds. Proc. Natl. Acad. Sci. USA. 75:2458-2462.

6. Newburger, P. E., M. E. Chovmiec, J. S. Greenberger, and H. J. Cohen. 1979. Functional changes in human leukemic cell line HL-60. J. Cell Biol. 82:315-322.

7. Boss, G. R., and R. B. Pilz. 1985. Phosphoribosylpyrophosphate synthesis from glucose decreases during amino acid starvation of human lymphoblasts. J. Biol. Chem. 260:6054-6059.

8. Boss, G. R., and R. W. Erbe. 1982. Decreased purine synthesis during amino acid starvation of human lymphoblasts. J. Biol. Chem. 257:4242-4247.

9. Breitman, T. R., S. E. Selonick, and S. J. Collins. 1980. Induction of differentiation of the human promyelocytic leukemia cell line (HL60) by retinoic acid. Proc. Natl. Acad. Sci. USA. 77:2936-2940.

10. Grummt, F., and I. Grummt. 1976. Studies on the role of uncharged tRNA in pleiotypic response of animal cells. Eur. J. Biochem. 64:307-312.

11. Vaughan, G. H., and B. S. Hansen. 1973. Control of initiation of protein synthesis in human cells. Evidence for a role of uncharged transfer ribonucleic acid. J. Biol. Chem. 248:7087-7096.

12. Pestka, S. 1977. Inhibitors of protein synthesis. In Molecular Mechanisms of Protein Biosynthesis. H. Weissbach and S. Pestka, editors. Academic Press, New York. 468-555.

13. Ogilvie, A., U. Huschka, and W. Kersten. 1979. Control of protein synthesis in mammalian cells by aminoacylation of transfer ribonucleic acid. Biochim. Biophys. Acta. 565:293-304.

14. Smulson, M. E., and J. Thomas. 1969. Ribonucleic acid biosynthesis of human cells during amino acid deprivation. J. Biol. Chem. 244: 5309-5312.

15. Dehlinger, P. J., T. A. Hamilton, and M. Ritt. 1977. Amino acid control of stable RNA synthesis in Friend Leukemia cells in relation to intracellular purine nucleoside triphosphate levels. Eur. J. Biochem. 77: 495-499.

16. Thomas, G. P., and M. B. Mathews. 1984. Alterations of transcription and translation in HeLa cells exposed to amino acid analogs. Mol. Cell. Biol. 4:1063-1072.

17. Boss, G. R. 1984. Decreased phosphoribosylpyrophosphate as the basis for decreased purine synthesis during amino acid starvation of human lymphoblasts. J. Biol. Chem. 259:2936-2941.

18. Sueoka, N., and T. Kano-Sueoka. 1970. Transfer RNA and cell differentiation. Prog. Nucleic Acid Res. Mol. Biol. 10:23-55.

19. Lin, V. K., and P. F. Agris. 1980. Alterations in tRNA isospecies during erythroid differentiation of the Friend leukemia cell. Nucleic Acids Res. 8:3467-3479.

20. Fournier, M. J., and A. Peterkovsky. 1975. Formation of chromatographically unique species of transfer ribonucleic acid during amino acid starvation of relaxed-control Escherichia coli. J. Bacteriol. 122:538548.

21. Smith, D. W. E. 1975. Reticulocyte transfer RNA and hemoglobin synthesis. Science (Wash. DC). 190:529-535.

22. Carpousis, A., P. Christner, and J. Rosenbloom. 1977. Preferential usage of tRNA isoaccepting species in collagen synthesis. J. Biol. Chem. 252:8023-8026. 